\title{
Impact of Typeface and Colour Combinations on LCD Display Legibility
}

\author{
Gregor Franken a ${ }^{\text {, Maruša Pangerc }}{ }^{\text {a }}$, Klementina Možina ${ }^{\mathrm{a}^{*}}$ \\ ${ }^{a}$ Department of Textiles, Graphic Arts and Design, Faculty of Natural Sciences and Engineering, University of Ljubljana, SI-1000 \\ Ljubljana, Slovenia
}

\begin{abstract}
The evolution of high resolution displays, especially liquid crystal displays (LCD), which are among the most commonly used ones, has contributed to a larger number of display readers. Regardless of high resolutions, problems in the legibility of typefaces still occur. Many typefaces may well be readable in print, but cause more difficulties when being read on displays. The aim of this study was to examine the influence of colour contrast on the legibility on LCDs to establish which type style is appropriate for a coloured text to be legible. Two different typefaces specially designed for display use were tested in a satisfactory light-dark contrast of five different colour combinations. The reading speed and fixations were analysed with an eye-tracking device Tobii 120X. Different texts were displayed on an LCD display. The results showed that the selection of a particular colour combination and contrast greatly affects the reading speed and legibility. Less visible colour combinations of text and background were read more slowly than the more contrasting or visible ones in both typefaces. At both typefaces, it was seen that at a slower reading speed, more fixations were needed and vice-versa. A transitional typeface gave a faster reading speed than a sans-serif typeface. An appropriate contrast, colour combination and used typography can facilitate legibility on displays.
\end{abstract}

\section{Keywords:}

Colour Combination

Eye-Tracking Technology;

LCD Display;

Legibility;

Reading;

Typography.

Article History:

$\begin{array}{llll}\text { Received: } & 30 & \text { July } & 2020 \\ \text { Accepted: } & 19 & \text { November } & 2020\end{array}$

\section{1- Introduction}

A constant rise in technology and the expansion of the Internet are two main factors which have contributed to the decline of the use of printed media and caused a continuously growing number of display readers. This has brought the evolution of high resolution displays, especially liquid crystal displays (LCD), which are among the most commonly used ones. Regardless of high resolutions, problems in the legibility of typefaces still occur. Many typefaces may well be readable in print, but cause more difficulties when being read on displays. For better display legibility, the typefaces Georgia [1], i.e. transitional type style [2,3], and Verdana [4], i.e. sans-serif type style [2, 3], have been designed.

The communication through a page or a display requires from the reader to translate symbols into meaning. Legibility refers to how easily this process is performed. To make reading possible, the text must be visible and recognisable; however, visibility and recognition are influenced by the typography choice. Furthermore, legibility is also influenced by the reader's verbal capabilities $[5,6]$.

Legibility and the reading process can be studied by tracking eye movement. Reading does not occur as a continuous movement of eyes along the lines of a text, but rather as a sequence of rapid eye movements (saccades) (cf. Figure 1) and individual fixations (cf. Figure 2), which typically last between 200 and $250 \mathrm{~ms}$ [7, 8]. Fixations are short stops at individual words or groups of words that (within their duration) enable the brain to process information.

\footnotetext{
* CONTACT: Klementina.mozina@ntf.uni-lj.si
}

DOI: http://dx.doi.org/10.28991/esj-2020-01243

(C) 2020 by the authors. Licensee ESJ, Italy. This is an open access article under the terms and conditions of the Creative Commons Attribution (CC-BY) license (https://creativecommons.org/licenses/by/4.0/). 
On the other hand, saccades are extremely rapid eye movements, the function of which is to align the image of the object with the area of the fovea. Based on the data of fixations and saccades, as well as the reading speed, we can draw conclusions about the reading process and the legibility of a text.

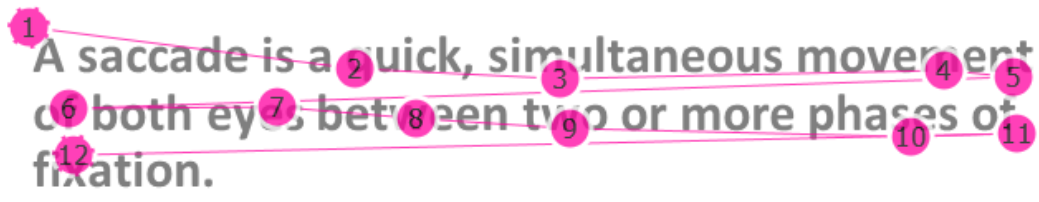

Figure 1. Example of saccades.

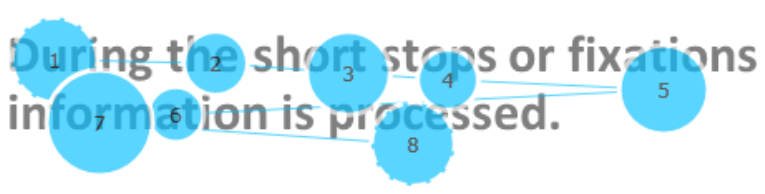

Figure 2. Example of fixations.

A large number of studies on legibility points to its importance. There is a big discrepancy in understanding what makes a text legible. Nevertheless, it is possible to determine some general guidelines that can help make a text legible. There are some typographic characteristics to be observed to make a text more legible. For a small type size, it is known that the differences in stroke weight and typographic tonal density (TTD) are significant [9, 10], since they influence text legibility. Furthermore, a number of other typographic characteristics needs to be observed in order to make a text more legible, i.e. distinctive character features (counter shape), x-height, ascender, descender, serifs, contrast (stroke weight), set width, type size, leading (i.e. space between lines) etc. [5, 6, 11-14]. Sans-serif typefaces consist of only main thick strokes and are of simpler shape (cf. Figure 3).

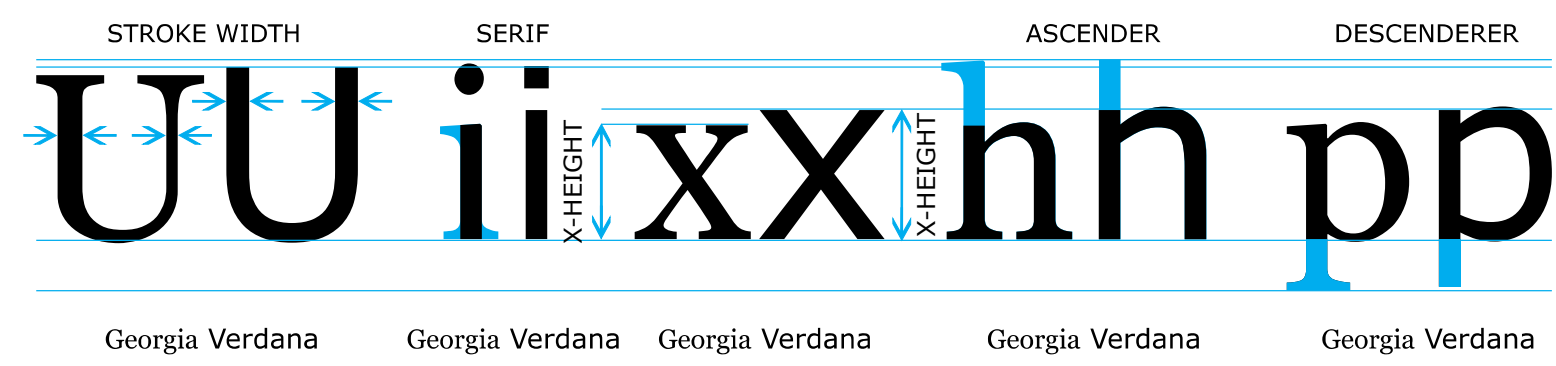

Figure 3. Some typographic characters of Georgia and Verdana typefaces that influence legibility of texts: difference in stroke width, serifs, $x$-height, and properties of ascenders and descenders.

For better visibility of information, colour can be of use as well [15]. Most typefaces are designed to be read as black letters on a white background and they in this manner achieve optimum legibility. Leaving no ambiguity, black and white are completely balanced opposites, offering exquisite contrast. When reading large amounts of type, the contrast of black and white is what readers are most accustomed to [16, 17]. When colour is used for better typographic visibility, the contrast is poorer and we therefore have to take into consideration some results of previous research [15-17]. As type decreases in size, colour contrast has to increase in strength [16, 17]. Letter and word spacing, and leading affect type colour (TTD). Similarly, when letter and word spacing, and leading increase, TTD decreases $[6,16,18]$. Hence, when colour is used to improve visibility, a larger type size or black typefaces or sansserif typefaces need to be used. Furthermore, larger leading should be applied when colour is used for typography or background or both $[6,16,17]$.

To attract the reader's attention, blue and red colours are often used with white background [19]. The red colour is associated with danger, energy or warmth [20]. It can activate avoidance motivation, enhance performance and detailoriented cognitive tasks [21], and in turn, it can lead to greater attention. The blue colour represents trust, hope and serenity [20]. Despite its subdued tone, the combination of blue and white can affect the recipient and is a visible source of additional information [20, 22].

The legibility study [23] of different typefaces in different light-dark contrasts with different backgrounds displayed on an LCD display showed that a better contrast (however, not maximum, i.e. black on white) increases the reading speed. Therefore, the aim of this study was to examine the influence of the colour combination on the legibility on LCD displays to establish which type style is suitable for a coloured text, making it legible. 


\section{2- Experimental}

The flowchart of the research methodology is shown in Figure 4. Two different, specially designed typefaces for display use (one transitional, i.e. Georgia, and one sans-serif, i.e. Verdana) were tested in five different colour combinations involving five colours, i.e. dark grey (\#1A1A1A) on white (\#FFFFFF) (Combination 1), dark blue (\#142451) on white (\#FFFFFF) (Combination 2), dark blue (\#142451) on light grey (\#D9D9D9) (Combination 3), red (\#C62026) on white (\#FFFFFF) (Combination 4) and red (\#C62026) on light grey (\#D9D9D9) (Combination 5).

In controlled laboratory conditions [24], the reading speed and fixations were analysed with an eye-tracking device Tobii 120X (cf. Figure 5). The texts in both typefaces at $12 \mathrm{pt}$ (points; 1 point $=4.233 \mathrm{~mm})(16 \mathrm{px}), 130 \%$ leading and all colour combinations were displayed on a 24-inch LCD display with the resolution of $1900 \times 1200$ pixels at $120 \mathrm{~Hz}$ refresh rate. The calculated values of the vertical view angle [25] were for the typeface Georgia $0.21^{\circ}$ and for Verdana $0.23^{\circ}$ (cf. Table 1). In each typeface and each colour combination, a different text was presented to tested individuals. We used ten different texts from National Geographic (Slovenian edition) with the length of between 97 and 115 words, each comprising between 10 and 13 lines (cf. Figures 6 and 7).

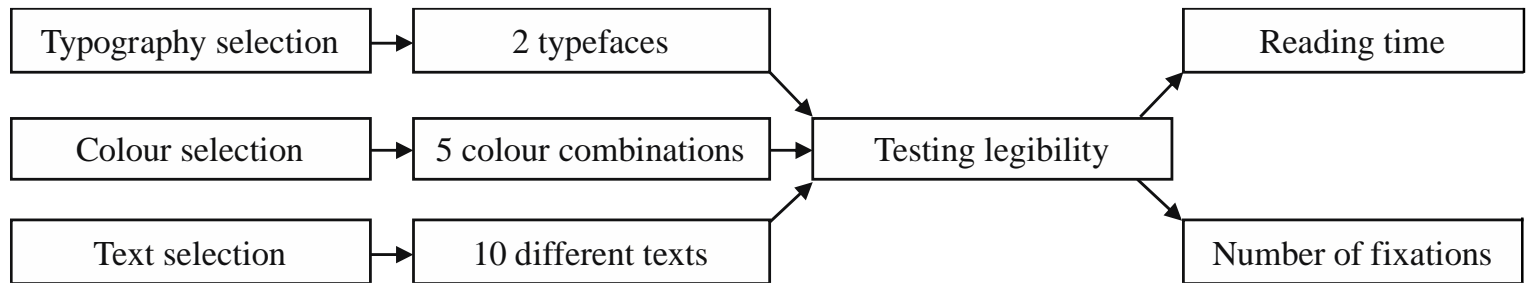

Figure 4. Flowchart of research methodology.

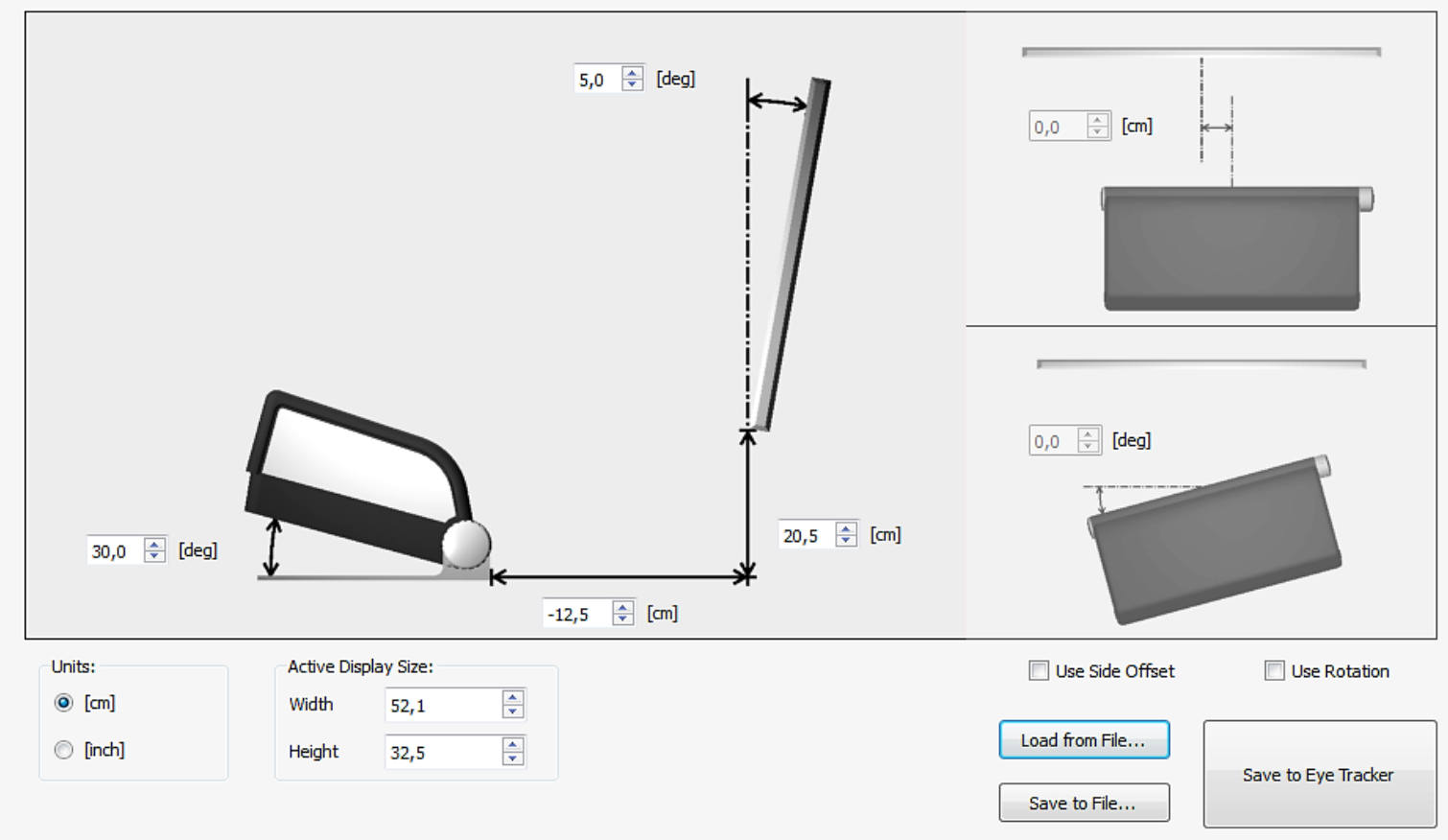

Figure 5. Entered parameters for placement of eye-tracking device.

Table 1. Sizes of $x$-height for Georgia and Verdana typeface display.

\begin{tabular}{ccc}
\hline x-height & Georgia & Verdana \\
\hline $\mathrm{x}(\mathrm{px})$ & 8 & 9 \\
$\mathrm{x}(\mathrm{mm})$ & 2.10 & 2.43 \\
$\mathrm{x}\left({ }^{\circ}\right)$ & 0.21 & 0.23 \\
\hline
\end{tabular}

The time required to read 600 characters (in seconds) and the number of fixations were calculated. Forty tested individuals were between 19 and 22 years old, with an average of 21.1 years. All participants had normal or correctedto-normal vision. In line with recommendations [26], they were positioned $60(+/-1) \mathrm{cm}$ from the display. The texts were set in a CSS style sheet and displayed as an HTML document. In this way, we ensured a precise display of texts 
in the chosen size. The texts were shown in the centre of the display. The display sequence varied using the Latin square design, which was used to counterbalance the order of texts.

Počepnem v travo, da bi si pobliže ogledala žival, ki se opoteka proti meni. Stara je približno štiri mesece, velika kot nogometna žoga, ima rahlo izbuljene oči in zagotovo je mehka in prijetnega vonja kot mlad kužek. Čutim neustavljivo željo, da bi jo dvignila in stisnila k sebi. Prav ta ljubkost je eden od razlogov, da je orjaški panda mednarodna znamenitost in hkrati kitajski kulturni simbol, gospodarska zlata jama in vir nacionalnega ponosa - Kitajska je namreč edina država, kjer še živijo ti azijski medvedi. Ves svet spremlja njena vztrajna prizadevanja, da bi se pande ohranili v naravnem okolju - v nekaterih pogledih je pri tem neverjetno uspešna.

Figure 6. Sample of text paragraph in Georgia typeface.

»Če ti zdrsne, se ne boš mogel ustaviti. Zgrmel boš v prepad, « je bevsknil Rich Rudow. Navadno ga nič ne vrže iz tira, toda še predobro je vedel, da to ni kraj, kjer bi si lahko privoščil nepazljivost. Bila sva v prepadni steni kakšnih 1000 metrov nad reko Kolorado, na vrhu slikovite, v rečni zavoj ujete planote Great Thumb Mesa, ki moli z južnega roba Velikega kanjona kot premec velikanske ladje. Če vam je uspelo priti tako daleč in stojite na robu Thumba, se do reke ne morete spustiti brez plezalne opreme, kopneče zaloge hrane $v$ nahrbtniku pa vam ne dopuščajo vračanja po poti, po kateri ste prišli.

Figure 7. Sample of text paragraph in Verdana typeface. 


\section{3- Results and Discussion}

Figure 8 shows the influence of the used typefaces and colour combinations on the reading speed. Figure 9 shows the influence of the used typefaces and colour combinations on the number of fixations. On average, the reading speed was faster at the combinations of the red text on white or light grey backgrounds (Combinations 4 and 5) (cf. Figure 8). At all examples, the texts set in the transitional typeface Georgia were read the fastest, regardless of the used colour combinations. On average, the texts set in the Verdana typeface were read the slowest, the only exception being dark grey text on white background (Combination 1). Verdana is a sans-serif typeface and should thus have better legibility at reading on displays than a transitional typeface [23]. Obviously, at this type size (16 px), big counter size, wide letters and thick stroke width led to a lower reading speed. An interaction between a greater number of fixations (cf. Figure 9) and slower reading was noticed, especially at the Verdana typeface. A larger counter size gave more fixations and consequently resulted in slower reading.

The results of the Franken (2015) [23] study showed that the reading speed increases when the background is not completely white. When light grey colour, not white, was used for background in our study, the fastest (Combination 5) and the slowest (Combination 3) reading speed was achieved (cf. Figure 8). Apparently, only one parameter does not affect the reading speed, while the combination of text colour and background colour together does.

A higher colour contrast results in better performance [27] and should give better results of legibility [19]. A moderate or even a high colour contrast does not guarantee quick visual perception [28] if the luminance contrast between the characters and background is small [29]. It was also interesting that the red text on white or light grey background (Combinations 4 and 5) gave the fastest reading speed (cf. Figure 8) and the smallest number of fixations (cf. Figure 9), since these colour combinations have the smallest light-dark contrast among the used colour combinations. Most likely, the unusual colour combination for a longer text (not only titles or a short text) gained more attention by the readers. It was surprising that the blue and white or light grey colour combinations with a strong enough light-dark contrast (Combinations 2 and 3) gave the worst legibility. The reason for this is in the number of cones sensitive to short-wavelength light at the peripheral retina, which is greater than in the fovea centralis [30]. There should be no problem with larger objects in blue, while typefaces with bigger counter sizes in smaller type sizes in blue obviously lead to worse legibility.

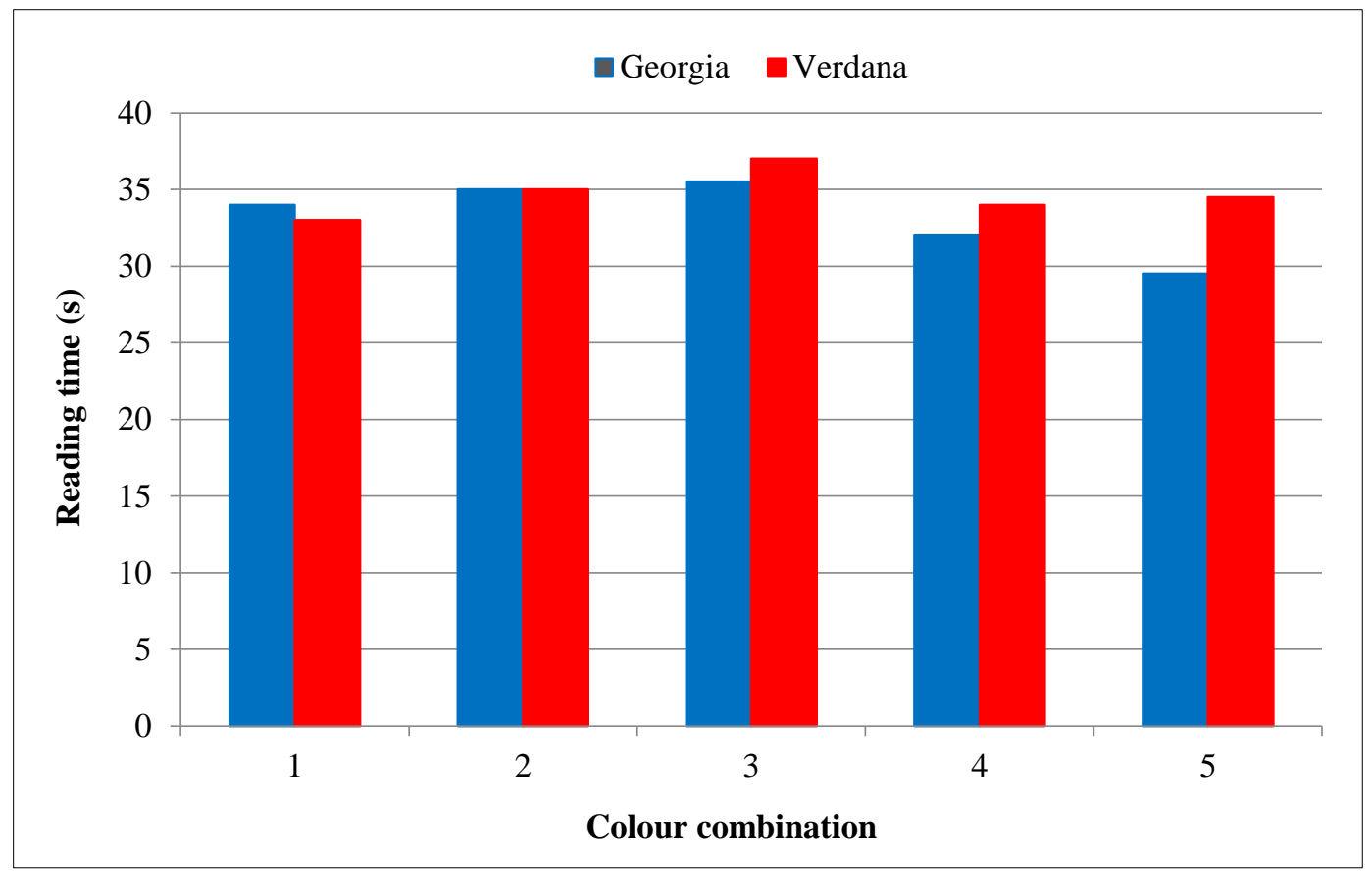

Figure 8. Reading time (s) of used typefaces in different colour combinations. 


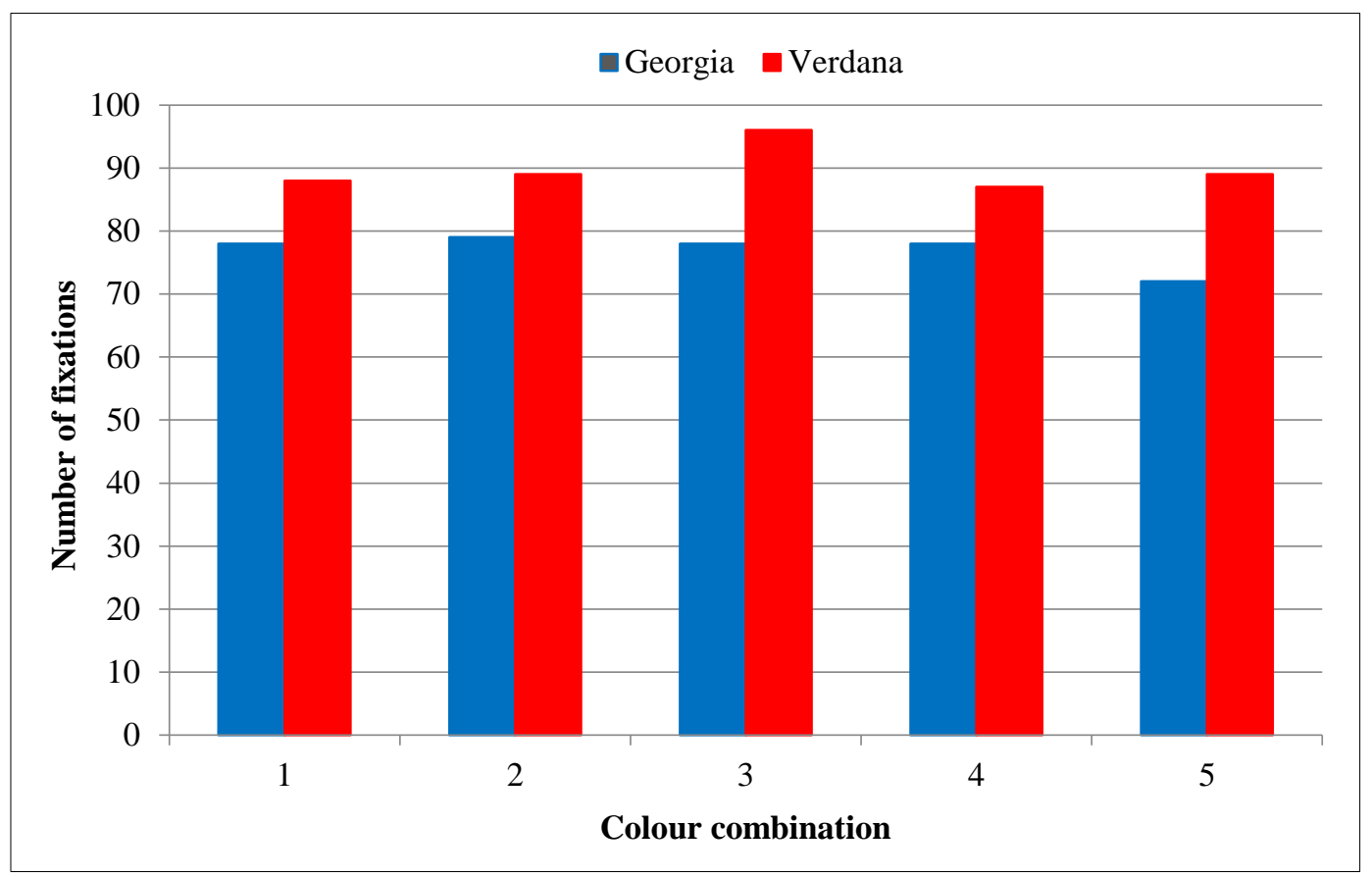

Figure 9. Number of fixations at used typefaces in different colour combinations.

\section{4- Conclusion}

In this study, we examined the influence of a colour combination on the legibility on LCD displays to establish which type style is suitable for a coloured text to be legible. The results showed that the reading speed and, consequently, the legibility of a text on an LCD display are influenced by the typeface. The texts set in the transitional typeface Georgia were read faster than the texts set in the sans-serif typeface Verdana. At both typefaces, it was seen that at a slower reading speed, more fixations were needed and vice-versa. Both typefaces used in our study have a larger x-height. Georgia has variations in stroke width, while Verdana does not. At the same time, Georgia has serifs, while Verdana does not. This usually contributes to faster information processing of a printed text. Both typefaces were specially designed for display use. Apparently, the transitional typeface Georgia is really useful for reading a text on displays. Nevertheless, different colour combinations had different reading speeds at different typefaces (transitional vs. sans-serif). The results of the study showed that the selection of a particular colour combination and contrast greatly affects the reading speed and legibility. Less contrasting or visible colour combinations of the text and background were read more slowly, i.e. blue and light grey or white, than the more contrasting or visible ones, i.e. red and light grey or white, at both typefaces. An appropriate contrast and colour combination can facilitate the legibility of displays. Consequently, in order to be able to give an appropriate suggestion for usable display legibility, the study should be thought through with more diverse colour combinations and contrasts.

\section{5- Conflict of Interest}

The author declares that there is no conflict of interests regarding the publication of this manuscript. In addition, the ethical issues, including plagiarism, informed consent, misconduct, data fabrication and/or falsification, double publication and/or submission, and redundancies have been completely observed by the authors.

\section{6- References}

[1] "Georgia.” Available online: https://en.wikipedia.org/wiki/Georgia_(typeface) (accessed on 17 July 2020).

[2] McLean, Ruari. The Thames and Hudson manual of typography. Thames and Hudson, (1980).

[3] Možina, K. "Knjižna tipografija,” [“Book typography”]. University of Ljubljana, Ljubljana, (2003).

[4] "Verdana.” Available online: https://en.wikipedia.org/wiki/Verdana (accessed on 17 July 2020).

[5] Reynolds, L. "Legibility of Type.” Baseline 10 (1988): 26-29.

[6] Možina, Klementina, Anja Podlesek, and Sabina Bračko. "Preserving Typographic Cultural Heritage Using Contemporary Digital Technology.” Journal of Cultural Heritage 36 (March 2019): 166-173. doi:10.1016/j.culher.2018.07.010.

[7] Rayner, Keith, Barbara R. Foorman, Charles A. Perfetti, David Pesetsky, and Mark S. Seidenberg. "How Psychological Science Informs the Teaching of Reading." Psychological Science in the Public Interest 2, no. 2 (November 2001): 31-74. doi:10.1111/1529-1006.00004. 
[8] Abadi, Richard V. "Vision and Eye Movements." Clinical and Experimental Optometry 89, no. 2 (February 22, 2006): 55-56. doi:10.1111/j.1444-0938.2006.00026.x.

[9] Možina, Klementina, Tanja Medved, Blaž Rat, and Sabina Bračko. "Influence of Light on Typographic and Colorimetric Properties of Ink Jet Prints." Journal of Imaging Science and Technology 54, no. 6 (2010): 060403. doi:10.2352/j.imagingsci.technol.2010.54.6.060403.

[10] Rat, Blaž, Klementina Možina, Sabina Bračko, and Anja Podlesek. "Influence of Temperature and Humidity on Typographic and Colorimetric Properties of Ink Jet Prints." Journal of Imaging Science and Technology 55, no. 5 (2011): 050607. doi:10.2352/j.imagingsci.technol.2011.55.5.050607.

[11] Gaultney, V. "Balancing Typeface Legibility and Economy: Practical Techniques for the Type Designer," research essay. University of Reading, (2001).

[12] Bix, L. "The elements of text and message design and their impact on message legibility." Journal of Design Communication 4 (2002). Available online: http://scholar.lib.vt.edu/ejournals/JDC/Spring-2002/bix.html (accessed on 10 July 2020).

[13] Tracy, W. "Letters of Credit: A View of Type Design.” David R. Godine, Boston, (2003).

[14] Franken, G., Podlesek, A., and K. Možina. "Eye-tracking Study of Reading Speed from LCD Displays: Influence of Type Style and Type Size.” Journal of Eye Movement Research 8, no. 1 (2015): 1-8. doi:10.16910/jemr.8.1.3.

[15] White, J. V. “Color for impact.” Strathmoor Press, Berkeley (1996).

[16] Carter, R. "Working with computer type.” Rotovison, Crans, (1997).

[17] Možina, K. "Barva v tipografiji, Interdisciplinarnost barve, del 1," ["Colour in typography, Interdisciplinarity of colour, part 1”]. Društvo koloristov Slovenije, Maribor, (2001): 341-364.

[18] Keyes, E. “Typography, color, and information structure.” Technical Communication 4, no. 4 (1993): 638-654.

[19] Pušnik, N. Podlesek, A., Nedeljković, U., and K. Možina. "Effects of colour combination on short-words processing speed." Technical gazette 26, no. 3 (June 2019): 823-830. doi:10.17559/TV-20180109110718.

[20] Thussu, D. K. News as Entertainment. Sage, London, (2007): 43-45.

[21] Mehta, R., and R. Zhu. "Blue or Red? Exploring the Effect of Color on Cognitive Task Performances." Science 323, no. 5918 (February 27, 2009): 1226-1229. doi:10.1126/science.1169144.

[22] Deidre, K. "Europe in the Media, A comparison of Reporting, Representation, and Rhetoric in National media Systems in Europe.” Routledge, New York, (2003).

[23] Franken, G. “Čitljivost upodobitev na LCD zaslonih ob različnih osvetlitvenih pogojih,” ["Legibility of information rendered on LCD on displays in different light conditions”], PhD thesis. University of Ljubljana, Ljubljana, (2015).

[24] "ISO 3664: Graphic technology and photography - Viewing conditions." International Organization for Standardization, Geneva, (2009).

[25] Legge, G. E., and C. A. Bigelow. "Does Print Size Matter for Reading? A Review of Findings from Vision Science and Typography.” Journal of Vision 11, no. 5 (August 9, 2011): 8-8. doi:10.1167/11.5.8.

[26] "ISO 9241-303: Ergonomics of human-system interaction - Part 303: Requirements for electronic visual displays." International Organization for Standardization, Geneva, (2012).

[27] Lin, Chin-Chiuan. "Effects of Contrast Ratio and Text Color on Visual Performance with TFT-LCD.” International Journal of Industrial Ergonomics 31, no. 2 (February 2003): 65-72. doi:10.1016/s0169-8141(02)00175-0.

[28] Yue, S., Jin, Z., Fan, C., Zhang, Q., and L. Li. "Interference between smooth pursuit and color working memory.” Journal of eye movement research 10, no. 3 (2017): 1-10. doi:10.16910/jemr.10.3.6.

[29] Ojanpää, Helena, and Risto Näsänen. "Effects of Luminance and Colour Contrast on the Search of Information on Display Devices.” Displays 24, no. 4-5 (December 2003): 167-178. doi:10.1016/j.displa.2004.01.003.

[30] Krauskopf, J. “Color Vision.” Color for Science, Art and Technology. Elsevier, Amsterdam, (1998): 97-121. 